\title{
Assessment of metal concentrations in tap-water - from source to the tap: a case study from Szczecin, Poland
}

\author{
Józef Górski ${ }^{1}$, Marcin Siepak ${ }^{1, *}$ \\ ${ }^{1}$ Institute of Geology, Department of Hydrogeology and Water Protection, Adam Mickiewicz University, \\ Maków Polnych 16, 61-606 Poznań, Poland \\ * corresponding author; e-mail: Marcin.Siepak@amu.edu.pl
}

\begin{abstract}
The concentrations of $\mathrm{Al}, \mathrm{As}, \mathrm{Cd}, \mathrm{Cu}, \mathrm{Pb}, \mathrm{Zn}, \mathrm{Ni}$, Fe and Mn were determined in June 2010 for 100 tap-water samples, collected directly at consumers in the older part of the city of Szczecin (Poland). Increased concentrations of metals were thus detected. This concerns mainly Fe (19\% of samples showed concentrations above drinking-water quality standards) and $\mathrm{Pb}(5 \%)$. In some samples, the maximum admissible concentration levels for $\mathrm{Mn}, \mathrm{Cu}$ and Ni were also exceeded. This was not the case for Al, despite the use of aluminium compounds during water treatment; the $\mathrm{Al}$ concentrations in treated water were, however, significantly higher than in raw water.

It was also found that (1) the corrosive properties of water (low alkalinity and increased concentration of sulphates), (2) the water-treatment processes causing a decrease of the $\mathrm{pH}$ and an increase of the $\mathrm{CO}_{2}$, and (3) transport of the treated water over long distances $(30 \mathrm{~km})$ provide favourable conditions for the leaching of metals from water-pipe networks. The type of material used in domestic plumbing and the content of $\mathrm{Ce}, \mathrm{Fe}, \mathrm{Mn}, \mathrm{Ni}$ and $\mathrm{Cd}$ in the tap-water at consumers show a correlation. The high content of $\mathrm{Pb}$ is mainly a result of lead pipes connecting the network to the buildings.
\end{abstract}

Keywords: chemical quality; water-distribution networks; metals; tap-water

\section{Introduction}

The 1998 EU Directive 98/83 EC Directive on drinking-water establishes strict standards, based on healthcare criteria, for metals $(\mathrm{Sb}, \mathrm{Cd}$, $\mathrm{Cr}, \mathrm{Cu}, \mathrm{Pb}, \mathrm{Hg}, \mathrm{Ni}$ ) and metalloids (As, Se), as well as less strict standards for $\mathrm{Al}, \mathrm{Fe}, \mathrm{Mn}$ and $\mathrm{Na}$. The directive also emphasises maintaining appropriate water quality at the final point of water-works: the consumers' taps. In view of the above directive, which has also been adopted by Polish law, it is crucial to study the changes of the chemical composition in water from the water-capture, through the treatment process and the distribution of treated water to consumers. Studies of changes in the wa- ter composition allow for designing activities which should be undertaken in order to obtain and maintain a water quality meeting the directive standards at the consumers.

According to the studies that have been conducted to date, the major problem for consumers is posed by the leaching of such metals as $\mathrm{Pb}, \mathrm{Cu}$ and $\mathrm{Ni}$ from the distribution network and fittings (Schock, 1990; Smith, 1994; Sobesto, 1994; Toczyłowska, 1994; Al-Malack, 2001; Tamasi \& Cini 2004; Karavoltsos et al., 2008; Veschetti et al., 2010, Turek et al., 2011, Górski \& Siepak, 2011). The largest problem, however, is the leaching of lead, formerly used to manufacture the pipes. Moreover, components made of brass and soldering materials can also 
be a source of lead. According to data presented by Hayes et al. (2010), approx. 25\% of the houses in the European Union may have lead installations, mainly in the form of pipes connecting the buildings to the network. In such buildings, the concentrations of lead may exceed $10 \mu \mathrm{g} \cdot \mathrm{L}^{-1}$, which is the maximum admissible concentration in the EU (and also in Poland) since 2013.

In order to identify the above problem, analyses of metal concentration at consumers were conducted in Szczecin (NW Poland). The study area was the central part of the city, with old buildings fitted with lead pipes, in particular those connecting the buildings to the network. During the selection of the study area, factors favouring the leaching of metals from the distribution network were also taken into consideration: the corrosive properties of water (relatively low alkalinity and hardness of the raw water (which comes from Lake Miedwie) and the influence of aluminium sulphate, which is used during water treatment); the treated water is transported over $30 \mathrm{~km}$ through pipes made of iron.

\subsection{Selection of the study area}

The city of Szczecin was selected as it is one of ten problem areas in Poland for which detailed studies of metal concentrations at the consumers were conducted. It is one of the oldest and largest Polish cities. It is located in the north-western part of the country, in the province of Zachodniopomorskie, close to the Polish-German border (Fig. 1). The city covers an area of $301 \mathrm{~km}^{2}$, and has about 400,000 inhabitants (Dmochowska et al., 2010a,b). The city is divided into four quarters: Północ (North), Prawobrzeże (Right bank), Śródmieście (Centre) and Zachód (West).

The main source of water for the city is Lake Miedwie, located about $30 \mathrm{~km}$ south-east from the city centre (Fig. 1). It is a $16.2 \mathrm{~km}$ long and $3.2 \mathrm{~km}$ wide postglacial lake, with a surface area of $35.3 \mathrm{~km}^{2}$ and a maximum depth of $43.8 \mathrm{~m}$. The lake is located in a depression filled with silts, what hamper groundwater discharge to the lake. The water-capture facility, located along the lake with the water-treatment plant, produces about $85,000 \mathrm{~m}^{3}$ of water daily, which constitutes about $90 \%$ of the city's water demand. The remaining $10 \%$ of the supply is covered by groundwater.

\subsection{Objectives}

The study aimed to determine the influence of the above-mentioned factors favouring the leaching of metals from the water-distribution and water-transport networks on metal concentrations in consumers' tap-water in

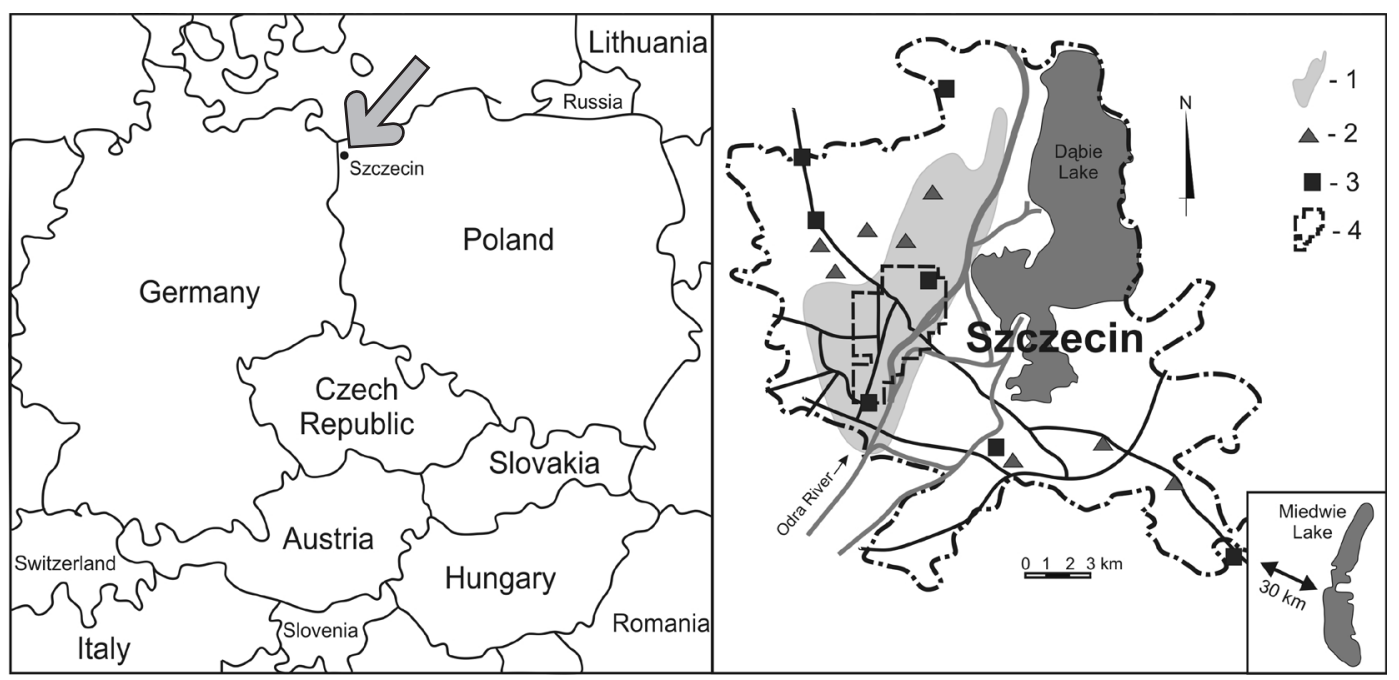

Fig. 1. Location of the study area.

1 - zone supplied with water from the Miedwie Lake in the left-bank part of Szczecin; 2 - pumping station; 3 - water-production plant; 4 - area investigated in detail. 
Szczecin. The study was conducted as part of the 'Metals and related substances in drinking water in Poland' project, carried out within the Cost Action 637.

\section{Materials and methods}

\subsection{Water-supply system}

The water from Lake Miedwie is taken by the water-supply authorities from a depth of 16-18 $\mathrm{m}$ below the water surface, i.e. $6 \mathrm{~m}$ above the bottom of the lake. The water is then transported to the treatment plant, which is located $425 \mathrm{~m}$ away from the lake. The treatment involves preliminary oxidation using ozone, coagulation with aluminium sulphate, quick filtration through open filters, intermediate ozonisation, and adsorption on carbon filters. Disinfection is performed using chlorine dioxide. The treated water is transported to the city through a 15-km long pipeline with a diameter of $1200 \mathrm{~mm}$, made of cast iron, then for another $15 \mathrm{~km}$ through a steel pipeline.

The total length of the pipeline network in Szczecin amounts to $1162 \mathrm{~km}$. About 39\% of the pipes in the distribution system are made of cast iron. The remaining pipes are made of steel (22\%), PE (17\%), PVC (11\%), asbestos cement $(3 \%)$, spheroid cast iron $(2 \%)$ and other materials $(6 \%)$. In the central part of the city, where the pipe network was constructed before 1900, the presence of lead pipes cannot be excluded, especially in the pipes connecting the buildings to the network.

\subsection{Characteristics of sampling points}

The study was carried out in the city center (Fig. 1). In this area, samples for physical-chemical analysis were collected mainly from buildings older than 30 years with connection pipes of at least the same age. The buildings are mainly apartments (58\% sampling points), and for the remaining part public buildings (29\%) and detached houses (13\%). The internal piping for water supply inside the buildings is 11-30 years old (62\%) (Fig. 2). The connection

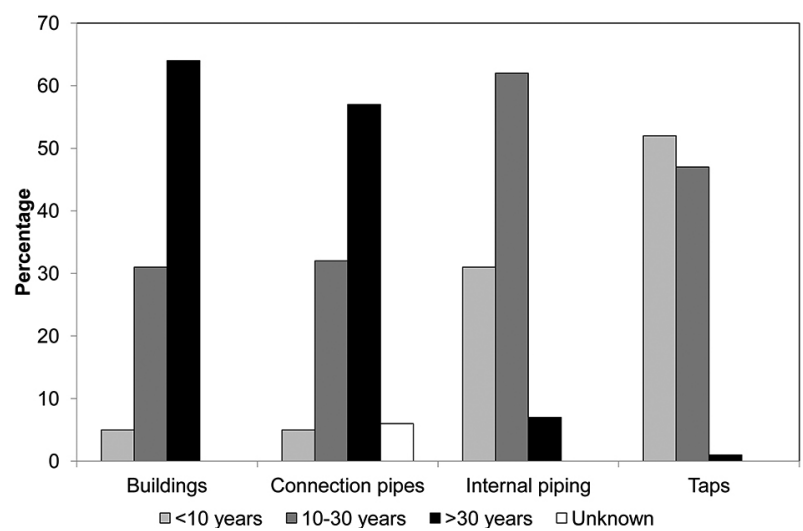

Fig. 2. Specification of the age of buildings, connection pipes, internal piping and taps of the sampling points in Szczecin (according to interviews with the householders).

pipes are mainly made of cast iron (56\%), while pipes inside the buildings are mainly made of galvanised steel (43\%) and copper (29\%). In the buildings of less than ten years old, the pipes are mainly made of PVC (4\%); in the buildings of over 30 years old, they are mainly made of galvanised steel $(27 \%)$ and copper $(19 \%)$. About half $(52 \%)$ of the taps where tap-water was collected is not older than 10 years and they are mostly made of brass coated with chromium.

\subsection{Sample collection}

The samples of tap-water were taken for chemical analysis in June 2010 using the random daytime sampling (RDT) method (Van den Hoven et al., 1999; Hoekstra et al., 2009). According to Hayes et al. (2010), this method, when applied to a large number of sampling points, allows for the identification of problems resulting from the leaching of metals from both distribution networks and domestic plumbing. The method involves collecting a water sample marked by a defined constant volume (1 litre) directly after opening the tap at a random time during the day. A total of 100 sites were sampled. The sampling covered $16 \mathrm{~km}^{2}$ of the city centre divided into squares forming a grid of $400 \times 400 \mathrm{~m}$, with sampling points located in the centre of the squares.

From the 1 litre of water that was collected at each sampling site, two $100-\mathrm{mL}$ samples that were to be used for the chemical analysis were stored in polyethene (HDPE) bottles produced 
by Nalgene ${ }^{\circledR}$. The samples for the study of metals were preserved with $0.5 \mathrm{~mL}$ of $60 \% \mathrm{HNO}_{3}$ Ultrapur $^{\circledR}$ (Merck, Darmstadt, Germany).

The $\mathrm{pH}$, the electrolytic conductivity and the temperature of the water were determined in the samples at the sampling sites using a Multi 350i/SET (WTW, Weilheim, Germany) meter equipped with $\mathrm{pH}$-Electrode SenTix 41 and TetraCon ${ }^{\circledR} 325$ electrodes produced by WTW. During the sampling process, data concerning the materials used in the construction of the domestic plumbing and of the pipes connecting it to the network, as well as information about the age of the building and the installation, were recorded. After sampling, the samples were taken to the chemical laboratory in a mobile refrigerator at a temperature of $4 \pm$ $2.5^{\circ} \mathrm{C}$.

\subsection{Chemical analyses}

Several techniques were used to determine the concentration of several elements in the water samples. For the determination of $\mathrm{Al}$, As, $\mathrm{Cd}, \mathrm{Ni}$ and $\mathrm{Pb}$, inductively coupled plasma mass spectrometry (ICP-MS) was applied (XSeries II CCT spectrometer, Thermo Electron Corporation, UK). For the determination of $\mathrm{Cu}, \mathrm{Fe}, \mathrm{Mn}, \mathrm{Zn}, \mathrm{Ca}, \mathrm{Mg}$ and $\mathrm{Na}$, inductively coupled plasma optical emission spectrometry (ICP-OES) with a CID detector was used (IRIS Advantage Duo ER/S spectrometer, Thermo Jarrell Ash, USA). The determinations of $\mathrm{Al}$, $\mathrm{Cd}, \mathrm{Cu}, \mathrm{Pb}, \mathrm{Zn}, \mathrm{Ni}, \mathrm{Fe}$ and $\mathrm{Mn}$ in raw water were conducted using atomic absorption spectrometry in the Szczecin Waterworks Laboratory. The $\mathrm{Cl}^{-}$and $\mathrm{SO}_{4}^{2-}$ concentrations were measured using ion chromatography (IC) with a Metrohm apparatus, model 881 Compact IC Pro (Metrohm AG, Herisau, Switzerland). Total alkalinity was measured by titration of a water sample against a methyl orange indicator. The operating conditions for ICP-MS, ICP-OES and IC analyses are listed in Tables 1 and 2.

Before the analysis, the samples were filtered through a filter with $0.45-\mu \mathrm{m}$ pore diameter produced by Millipore (Billerica, MA, UAS) and Sartorius AG (Sartorius AG, Germany). During the chemical analysis, clean reagents for trace-element analysis and de-ionised water purified in equipment produced by Millipore (Billerica, MA, UAS) were used. CRM TMDA-51.3 (Environment Canada), SRM 1643e (National Institute of Standards \& Technology, USA) and CRM RAIN-97 (Environ-

Table 1. Operating conditions for ICP-MS and ICP-OES determinations.

\begin{tabular}{|c|c|}
\hline \multicolumn{2}{|l|}{ ICP-MS } \\
\hline plasma torch & $\begin{array}{l}\text { quartz, } \\
\text { equipped with } \\
\text { silver screen }\end{array}$ \\
\hline nebulizer & glass concentric \\
\hline R.F. frequency & $27.12 \mathrm{MHz}$ \\
\hline forward power & $1400 \mathrm{~W}$ \\
\hline $\begin{array}{l}\text { argon flow rates }\left(\mathrm{L} \mathrm{min}^{-1}\right) \text { : } \\
\text { - cool } \\
\text { - auxiliary } \\
\text { - nebulizer }\end{array}$ & $\begin{array}{r}13.0 \\
0.72 \\
0.95\end{array}$ \\
\hline target analyte isotopes monitored & $\begin{array}{c}{ }^{27} \mathrm{Al},{ }^{75} \mathrm{As},{ }^{114} \mathrm{Cd} \\
{ }^{60} \mathrm{Ni},{ }^{208} \mathrm{~Pb}\end{array}$ \\
\hline internal standard & ${ }^{89} \mathrm{Y}$ \\
\hline sample pumping flow rate $\left(\mathrm{mL} \mathrm{min}^{-1}\right)$ & approx. 0.8 \\
\hline uptake and wash times & $60 \mathrm{~s}$ \\
\hline $\mathrm{LOD}\left(\mu \mathrm{g} \cdot \mathrm{L}^{-1}\right)$ & \\
\hline $\mathrm{Al}$ & 0.15 \\
\hline As & 0.15 \\
\hline $\mathrm{Cd}$ & 0.012 \\
\hline $\mathrm{Ni}$ & 0.08 \\
\hline $\mathrm{Pb}$ & 0.12 \\
\hline \multicolumn{2}{|l|}{ ICP-OES } \\
\hline plasma torch & $\begin{array}{l}\text { quartz, horizon- } \\
\text { tal duo }\end{array}$ \\
\hline nebulizer & glass concentric \\
\hline R.F. frequency & $27.12 \mathrm{MHz}$ \\
\hline forward power & $1150 \mathrm{~W}$ \\
\hline $\begin{array}{l}\text { argon flow rates: } \\
\text { - plasma }\left(\mathrm{L} \min ^{-1}\right) \\
\text { - intermediate }\left(\mathrm{L} \min ^{-1}\right) \\
\text { - optics interface }\left(\mathrm{L} \mathrm{min}^{-1}\right) \\
\text { - purging optics }\left(\mathrm{L} \mathrm{min}^{-1}\right) \\
\text { - purging CID detector (units) } \\
\text { - nebulizer pressure (psi) }\end{array}$ & $\begin{array}{r}15 \\
1 \\
4 \\
4 \\
80 \\
26\end{array}$ \\
\hline sample pumping flow rate $\left(\mathrm{mL} \mathrm{min}^{-1}\right)$ & approx. 2 \\
\hline rinsing time & $60 \mathrm{~s}$ \\
\hline \multicolumn{2}{|l|}{$\mathrm{LOD}\left(\mu \mathrm{g} \cdot \mathrm{L}^{-1}\right)$} \\
\hline $\mathrm{Cu}$ & 1.5 \\
\hline $\mathrm{Zn}$ & 0.49 \\
\hline $\mathrm{Fe}$ & 0.71 \\
\hline Mn & 0.19 \\
\hline $\mathrm{Ca}$ & 70 \\
\hline $\mathrm{Mg}$ & 64 \\
\hline $\mathrm{Na}$ & 56 \\
\hline
\end{tabular}


Table 2. General conditions and parameters of the analytical technique (IC).

\begin{tabular}{|c|c|c|c|}
\hline Analyse & Analytical parameters & Element & $\begin{array}{c}\text { LOD } \\
{\left[\mathrm{mg} \cdot \mathrm{L}^{-1}\right]}\end{array}$ \\
\hline anions & $\begin{array}{l}\text { Metrosep A Supp 5-150/4.0 column } \\
\text { Metrosep A Supp } 4 / 5 \mathrm{Guard} / 4.0 \\
\text { sequential suppression system: chemical suppressor MSM II and MCS } \\
\text { suppressor } \mathrm{CO}_{2} \text { conductivity detection } \\
\text { eluent: } 3.2 \mathrm{mmol} \mathrm{L}^{-1} \mathrm{Na}_{2} \mathrm{CO}_{3} / 1.0 \mathrm{mmol} \mathrm{L}^{-1} \mathrm{NaHCO}_{3} \text {, flow rate } 0.7 \mu \mathrm{L} \mathrm{min}{ }^{-1}\end{array}$ & $\mathrm{SO}_{4}^{2-}$ & 0.011 \\
\hline
\end{tabular}

ment Canada) were used as certified reference materials.

\section{Results}

\subsection{Quality of raw and treated water}

The water taken from Lake Miedwie is characterised by a relatively low alkalinity and hardness. The concentrations of sulphates and, to a lower extent, of chlorides are relatively high. The metal concentrations are low, far below the admissible level in water meant for consumption, following the national Polish standards (PMH, 2010) and the European Directive (EC, 1998). During the water treatment, the concentrations of $\mathrm{Mn}, \mathrm{Cu}, \mathrm{Fe}$, and $\mathrm{Zn}$ decrease, while the concentration of $\mathrm{Al}$ increased significantly, which may be ascribed to coagulation with aluminium sulphate. The concentration of aggressive $\mathrm{CO}_{2}$ also goes up during the treatment, as a result of $\mathrm{Al}_{2}\left(\mathrm{SO}_{4}\right)_{3}$ hydrolysis and the formation of $\mathrm{H}_{2} \mathrm{SO}_{4}$. Simultaneously the $\mathrm{pH}$ and alkalinity of the water decrease, which causes its corrosive properties (Rybicki, 2011). The corrosive properties of the treated water reach a value of 2.1 according to the Larson-Skold index (Larson \& Skold 1958), indicating its corrosive character. It should be emphasised, however, that the treated water meets the Polish and the European Union standards for drinking water (Table 3).

\subsection{Quality of the tap-water}

In the water collected at consumers, the $\mathrm{pH}$ ranged from 7.46 to 8.07 , and the electrolytic conductivity from 600 to $672 \mu \mathrm{S} \mathrm{cm}^{-1}$. The concentration of calcium was from 70.0 to 87.0 $\mathrm{mg} \cdot \mathrm{L}^{-1}$, magnesium from 12.8 to $17.3 \mathrm{mg} \mathrm{L}^{-1}$, sodium from 21.7 to $27.9 \mathrm{mg} \cdot \mathrm{L}^{-1}$ and chlorides from 47.6 to $66.6 \mathrm{mg} \mathrm{L}^{-1}$. The concentrations of sulphates (117.9-121.4 $\mathrm{mg} \mathrm{L}^{-1}$ ) and alkalinity (3.0-3.5 meq $\mathrm{L}^{-1}$ ) were slightly higher in the water at consumers than in the treated water (Table 3). The temperature of the water collected from the taps was also higher, which is relevant because a higher water temperature may accelerate the leaching of metals from the water pipe networks, as observed by Koh et al. (1991) and Al-Malack (2001).

The study of the metal contents at the consumers showed significantly higher concentrations of most metals than the treated water (Table 3), which must be ascribed to the leaching from the water pipe network. The increase concerned particularly $\mathrm{Fe}, \mathrm{Zn}$ and $\mathrm{Cu}$, as well as $\mathrm{Mn}$ and $\mathrm{Cd}$. Leaching from the network was indicated for $\mathrm{Pb}$ and $\mathrm{Ni}$ by maximum values, higher than those observed in the raw and the treated water. As a result of the increased metal concentrations in the tap-water at consumers, these concentrations sometimes exceed the admissible values for drinking water. This concerns $\mathrm{Fe}(19 \%$ of the analyses), $\mathrm{Pb}(5 \%), \mathrm{Ni}$ (1\%), Mn (1\%) and $\mathrm{Cu}(1 \%)$ (Fig. 3). The study also showed that the $\mathrm{Al}$ concentration in the water at consumers is higher than in the raw water of Lake Miedwie. This increase is due to the coagulation with $\mathrm{Al}_{2}\left(\mathrm{SO}_{4}\right)_{3}$. The maximum concentrations do, however, not exceed the admissible values (Fig. 3).

\section{Discussion regarding the threat to consumers}

The main threat to consumers is the occurrence of lead in concentrations which exceed the admissible values (5\% of the cases). The lead pipes in the water pipe network are the most likely $\mathrm{Pb}$ source in the tap-water. Nev- 


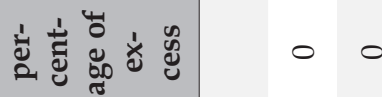

$\begin{array}{llllllllll}0 & 0 & 0 & 0 & 0 & -\pi & n\end{array}$

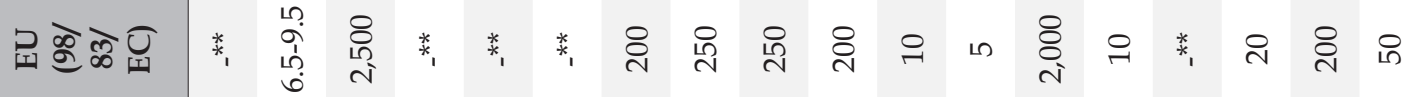

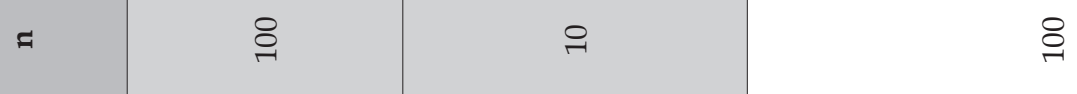

क

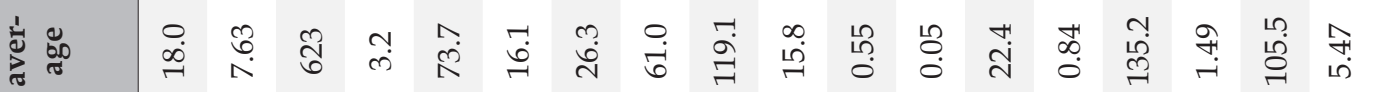

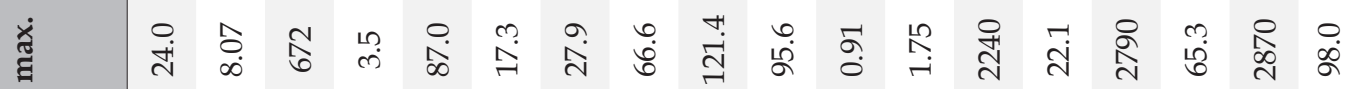

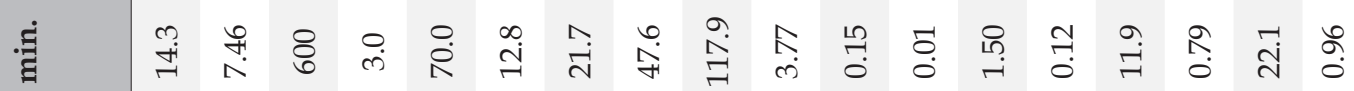

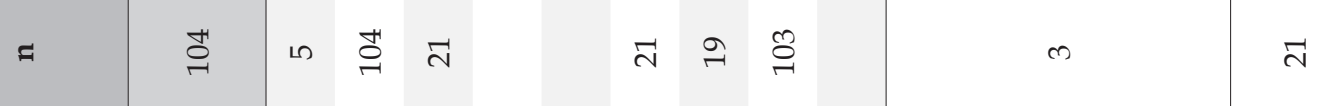
की मूँ

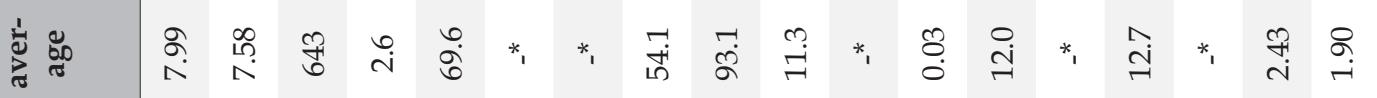

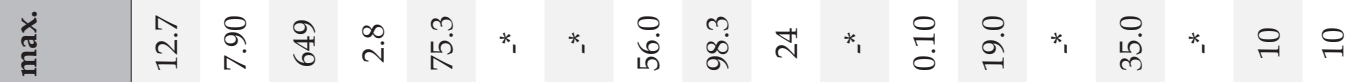

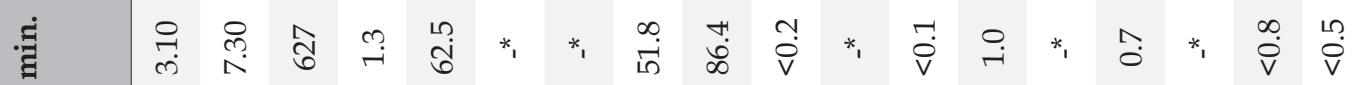

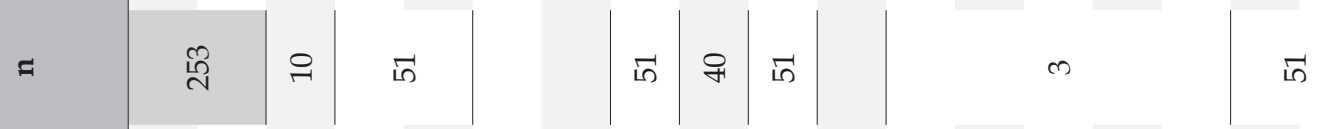

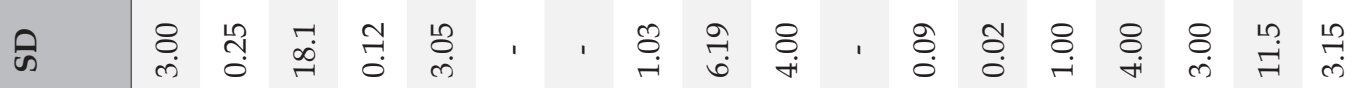

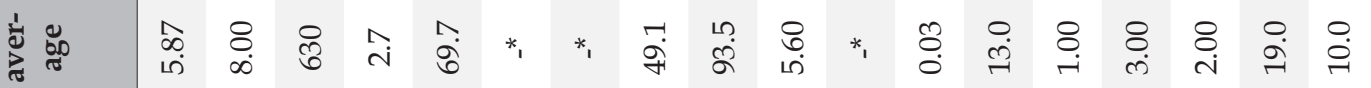

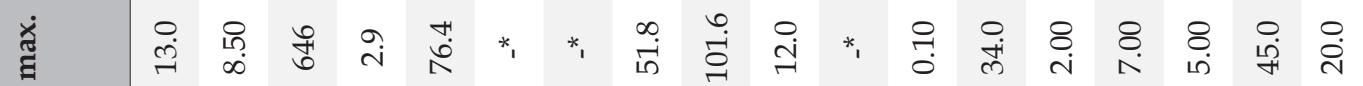

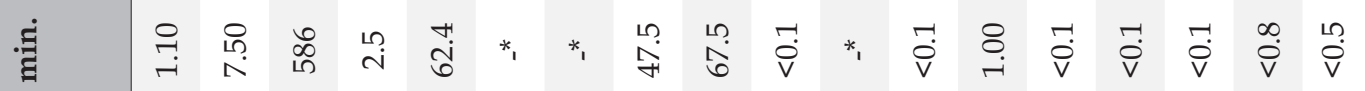

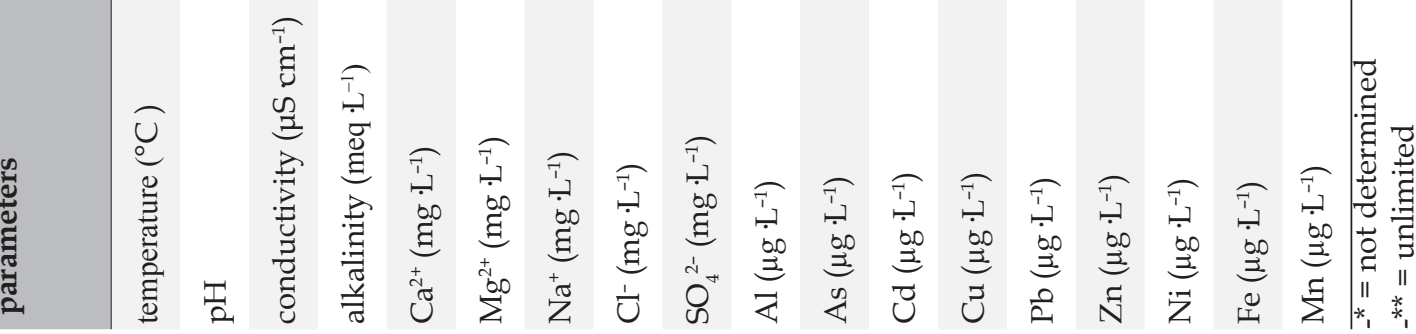


Fig. 3. Metal concentrations in tap water in Szczecin obtained using the random daytime method. NDS: above acceptable levels in drinking water.

ertheless, the average concentration of lead in the tap-water is low and in $90 \%$ of the samples it does not exceed $5 \mu \mathrm{g} \mathrm{L}^{-1}$. The maximum lead concentration is $22.1 \mu \mathrm{g} \mathrm{L}^{-1}$. Although the concentration of lead indicates a medium risk according to the classification of Hayes et al. (2010), it requires certain action in order to minimise this threat.

The most exceeded admissible values concern $\mathrm{Fe}(19 \%)$. This is a significant threat for the water consumers and requires remedial action (Hayes et al., 2010). The cause of the exceeded values is the leaching of Fe during the long-distance transportation of water over $30 \mathrm{~km}$ in steel and cast-iron pipes, as well as the leaching of Fe from domestic plumbing, especially if constructed from galvanised steel pipes (Fig. 4). It should be underlined that ferruginous deposits formed as a result of the corrosion of steel pipes may provoke the leaching of lead from pipes made of this material (Hayes et al., 2010).

The threat to the consumers due to the concentrations of $\mathrm{Ni}, \mathrm{Cu}$ and $\mathrm{Mn}$ is very low. Only single cases of exceeded admissible concentrations were found. In the case of $\mathrm{Cu}$, this concerns a building with an installation made of copper, and in the case of $\mathrm{Ni}$ and $\mathrm{Mn}$ installations of galvanised steel were responsible. The admissible values are not exceeded for As and

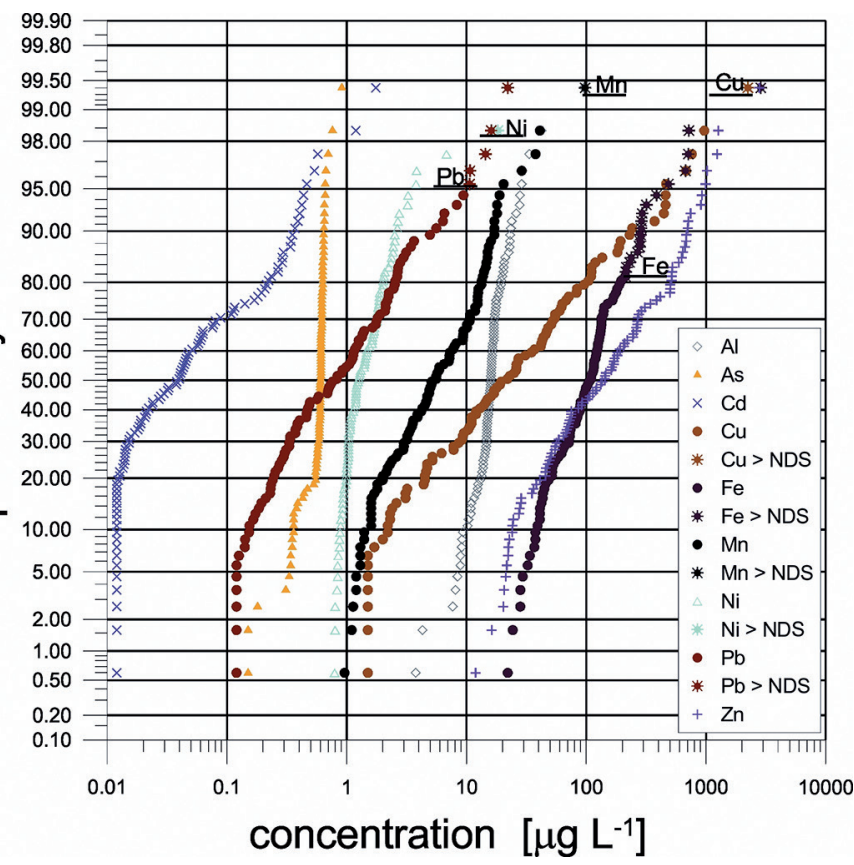

$\mathrm{Cd}$. However, intensive leaching of $\mathrm{Zn}$ from the water pipe network takes place. The maximum concentration of this metal amounts to $2790 \mu \mathrm{g} \mathrm{L}^{-1}$.

The type of material used in domestic plumbing appears correlatable with the metal concentrations in the tap-water (Fig. 4). In particular, higher concentrations of $\mathrm{Fe}, \mathrm{Mn}, \mathrm{Cd}$ and $\mathrm{Ni}$ were found in the tap-water of apartments with plumbing made of galvanised steel pipes and copper pipes, which has also been reported by Smith (1994) and Toczyłowska (1994). Slightly higher $\mathrm{Pb}$ concentrations were also found in the apartments with galvanised steel pipes (Fig. 4). However, the differences between the analysed installation types are minor, which suggests that the pipes made of lead in the water pipe network are the main source of this metal, which was also noticed by Cheng \& Foland (2005). A certain influence of PVC pipes plasticised with lead is also possible, as noted earlier by Koh et al. (1991) and AlMalack (2001). It is worth mentioning here that no significant differences in Zn concentrations for particular installation types were found, which might indicate that the main source of this metal are taps, along with the connections to the pipe. 

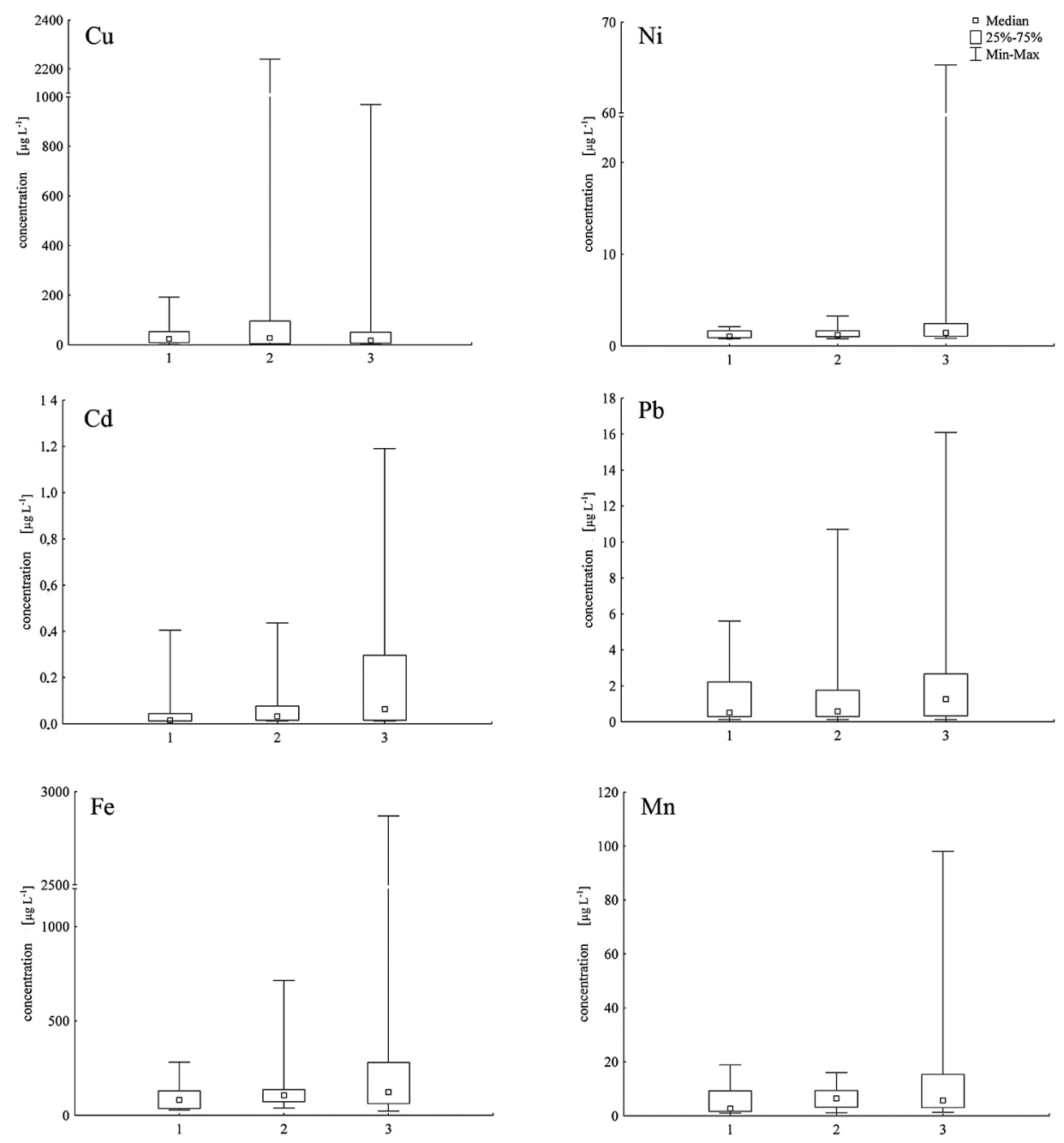

Fig. 4. Metal concentrations in tap water depending on the type of material used in domestic plumbing (1PVC pipes; 2 - copper pipes; 3 - galvanised pipes).

\section{Conclusions}

The study of water at consumers in Szczecin using the RDT sampling method indicated higher metal concentrations than in raw and treated water. This concerns especially Fe, Zn and $\mathrm{Cu}$, and to a lesser extent $\mathrm{Mn}$ and $\mathrm{Cd}$. In the case of $\mathrm{Pb}$ and $\mathrm{Ni}$, higher maximum concentrations were found, which do not occur in raw and treated water. The study shows very low concentrations of As and their minor distribution, which does indicate the absence of leaching of this metalloid from the distribution network. For $\mathrm{Al}$, a significant increase in concentration was found in treated water, which results from the application of coagulation with aluminium sulphate. A certain increase in concentration was also found at consumers. However, due to the lack of network elements constructed from this metal, this phenomenon should be linked to the leaching of $\mathrm{Al}$ from sediments accumulated in the network.

The significant increase of the Fe concentration should be ascribed mainly to the leaching of this metal from the water-distribution network between the water-treatment station and consumers over a distance of more than $30 \mathrm{~km}$. The high $\mathrm{Pb}$ concentration, exceeding the admissible standard, should in turn be linked to the leaching of this element from lead pipes connecting the network to the buildings, which conclusion must be drawn on the basis of the information obtained from the residents. The leaching of $\mathrm{Cu}$ and, to a certain extent, of $\mathrm{Ni}, \mathrm{Mn}$ and $\mathrm{Cd}$ occurs mainly in the internal plumbing system, as a high $\mathrm{Cu}$ concentration was found in installations made of copper, 
whereas increased $\mathrm{Fe}, \mathrm{Ni}, \mathrm{Cd}$ concentrations and, to a lesser extent, Mn concentrations occur in installations made of galvanised steel pipes.

\section{Acknowledgements}

The authors like to thank Dr S. Garboś and D. Święcicka, M.Sc., the employees of the National Institute of Public Health - National Institute of Hygiene in Warsaw (Poland) for performing the analyses of the metals in the water samples collected at consumers. The research was financed by the 2009-2010 research fund (project No. 398/N COST/2009/0) of the Polish Ministry of Science and Higher Education.

\section{References}

Al-Malack, M.H., 2001. Migration of lead from unplasticized polyvinyl chloride pipes. Journal of Hazardous Materials B82, 263-274

Cheng, Z. \& Foland, K.A., 2005. Lead isotopes in tap water: implications for $\mathrm{Pb}$ sources within a municipal water supply system. Applied Geochemistry 20, 353-365.

Cost Action 637. METEAU - Metals and related substances in drinking ater. http:/ / www.cost.eu.

Dmochowska, H. (Ed.), 2010a. Concise statistical yearbook of Poland. Central Statistical Office (Warszawa).

Dmochowska, H. (Ed.), 2010b. Demographic yearbook of Poland. Central Statistical Office (Warszawa).

EC (European Commission), 1998. Council directive of 3 November 1998 on the quality of water intended for human consumption EC Report 98/83/EC, 90-112.

Edwards, M. \& Dudi, A., 2004. Role of chlorine and chloramine in corrosion of lead-bearing plumbing materials. Journal of the American Water Works Association 96(10), 69-81.

Górski, J. \& Siepak M., 2011. Metals and related substances in drinking water at consumers in Poznan. Polish Geological Institute Bulletin 445, 139-148.

Hayes, C., Aergeerts, R., Barrott, L., Becker, A., Benoliel, M.J., Croll, B., Edwards, M., Gari, D., Hoekstra, E., Jung, M., Postawa, A., Ruebel, A., Russell, L., Schock, M.R., Skubala, N., Witczak, S., Tielemans, M. \& Zabochnicka-Świątek, M., 2010. Best practice guide on the control of lead in drinking water. IWA Publishing (London), $85 \mathrm{pp}$.

Hoekstra, E., Hayes, C., Aertgeerts, R., Becker, A., Jung, M., Postawa, A., Russell, L. \& Witczak, S., 2009. Guidance on sampling and monitoring for lead in drinking water. JRC Scientific and Technical Reports, EUR 23812 EN, $27 \mathrm{pp}$.

Hong, P.K.A. \& Macauley, Y.Y., 1998. Corrosion and leaching of copper tubing exposed to chlorinated drinking water. Water and Air Soil Pollution 108, 457-471.

Karavoltsos, S., Sakellari, A., Mihopoulos, N., Dassenakis, M. \& Scoullos, M.J., 2008. Evaluation of the quality of drinking water in regions of Greece. Desalination 224, 317-329.

Koh, L.L., Wong, M.K., Gan, L.M. \& Yap, C.T., 1991. Factors affecting the leaching of lead from UPVC pipes. Environmental Monitoring and Assessment 19, 203-214.

Larson, T.E. \& Skold, R.V., 1958. Laboratory studies relating mineral quality of water to corrosion of steal and cast iron. Illinois State Water Survey (Champaign, IL) Report ISWS C-71, 43-46

PMH (Polish Minister of Health), 2010. Rozporządzenie Ministra Zdrowia z 20 kwietnia 2010 r., zmieniajace rozporządzenie w sprawie jakości wody przeznaczonej do spożycia przez ludzi. Dziennik Ustaw - [Polish Journal of Laws] 72, item 466, 14 pp.

Rybicki S., 2011. Metals and metalloids introduced to water in treatment processes and distribution. [In:] A. Postawa \& S. Witczak (Ed.): Metals and related substances in drinking water in Poland. AGH (Craców), 81-96.

Schock, M.R., 1990. Internal corrosion and deposition control. [In:] F.W. Pontius (Ed.): Water quality and treatment ( $4^{\text {th }}$ ed.). McGraw-Hill Inc. (New York), 997-1111.

Smith, D.W., 1994. Water quality in distribution systems: challenges and solutions. [In:] M. Sozański (Ed.): Municipal and rural water supply and water quality. PZITS (Poznań), 3-16.

Sobesto, J., 1994. Effect of some selected physico-chemical parameters of water on deposit formation and pipeline corrosivity. [In:] M. Sozański (Ed.): Municipal and rural water supply and water quality.. PZITS (Poznań), 997-1002.

Tamasi, G. \& Cini, R., 2004. Heavy metals in drinking waters from Mount Amiata (Tuscany, Italy). Possible risks from arsenic for public health in the Province of Siena. Science of the Total Environment 327, 41-51.

Toczyłowska, B., 1994. Effects of internal corrosion of pipes in water distribution networks on drinking-water quality. [In:] M. Sozański (Ed.): Municipal and rural water supply and water quality. PZITS (Poznań), 45-54.

Turek, N.F., Kasten L., Lytle D.A. \& Goltz M.N., 2011. Impact of plumbing age on copper levels in drinking water. Journal of Water Supply Research and Technology - AQUA 60, 1-15.

Van den Hoven, Th.J.J., Buijs, P.J., Jackson, P.J., Miller, S., Gardner, M., Leroy, P., Baron, J., Boireau, A., Cordonnier, J., Wagner, I., Marecos do Monte, H., Benoliel, M.J., Papadopoulos, I. \& Quevauviller, Ph., 1999. Developing a new protocol for the monitoring of lead in drinking water. European Commission, BCR Information, Chemical Analysis, Report EUR 19087 EN, 23 pp.

Veschetti, E., Achene, L., Ferretti, E., Lucentini, L., Citti, G., Ottaviani, M., 2010. Migration of trace metals in Italian drinking waters from distribution networks. Toxicological and Environmental Chemistry 92, 521-535.

Manuscript submitted 15 May 2013 Revision accepted 25 February 2014 